\title{
FLUCTUATIONS OF THE TERMINUS OF THE HARALD MOLTKE BRÆ, GREENLAND
}

\author{
By Steven J. Mock \\ (U.S. Army Cold Regions Research and Engineering Laboratory, Hanover, New Hampshire, \\ U.S.A.)
}

\begin{abstract}
The terminus position of the Harald Moltke Bræ has been mapped from existing maps and from aerial and terrestrial photographs for the years $1946-47,1954,1956,1962$ and 1965 . When abetted by Wright's earlier work, a fairly detailed record of terminus position exists for the period I 916 to 1965 . The glacier has been in nearly continuous retreat during this period interrupted by a slight advance from 1926 to 1932 . Loss of area has been accelerating since $1946-47$. Ice flow velocity near the terminus has fluctuated through a known range from $30 \mathrm{~m}$./yr. to over $1,000 \mathrm{~m}$. $/ \mathrm{yr}$.
\end{abstract}

RÉsumé. Fluctuations du front du Harald Moltke Bra, Groenland. La position du front du Harald Moltke Bræ a été située à partir de cartes existantes et de photographies aériennes et terrestres pour les années $1946-47$, I954, I956, I962 et 1965. Stimulé par les travaux antérieurs de Wright, il existe pour la période allant de I 916 à 1965 un rapport assez détaillé concernant la position du front. Le glacier a été pratiquement en retrait continu pendant cette période, interrompu par une légère avance de 1926 à 1932 . La réduction de surface s'accélère depuis $1946-47$. La vitesse de la glace au voisinage de l'extrémité a varié dans les limites connues de $30 \mathrm{~m}$ par an à plus de $\mathrm{I}$ ooo $\mathrm{m}$ par an.

Zusammenfassung. Schwankungen der Zunge des Harald-Moltke-Bres, Grönland. Die Lage der Zunge des Harald-Moltke-Bræs wurde für die Jahre $1946-47,1954,1956$, I962 und 1965 aus bestehenden Karten, Luftbildern und terrestrischen Aufnahmen kartiert. Ergänzt durch die früheren Arbeiten von Wright, besteht so ausreichend detaillierte Kenntnis über die Lage der Gletscherzunge für die Zeit von I916 bis 1965 . Der Gletscher befand sich während dieser Zeit fast ständig im Rückgang, unterbrochen nur durch einen geringfügigen Vorstoss von 1926 bis 1932 . Der Flächenverlust hat sich seit 1946-47 beschleunigt. In der Geschwindigkeit der Eisbewegung nahe der Gletscherzunge konnten Schwankungen in einem Bereich von $30 \mathrm{~m}$ pro Jahr bis mehr als $1000 \mathrm{~m}$ pro Jahr festgestellt werden.

\section{INTRODUCTION}

Given certain parameters characteristic of the glacier in question, recent theoretical work (Nye, I965) has demonstrated the feasibility of calculating budget histories of glaciers from records of terminal advance and retreat. At present this treatment has been confined to alpine-type glaciers having their termini on land. This type of analysis may well be extended to glaciers ending in water, albeit with some added complexity, at which stage many of the large outlet glaciers of the Greenland Ice Sheet could become subject to such study.

Historical variations of terminal positions are recorded for scores of glaciers in the mountains of the temperate regions. Such is not the case for the polar regions where records are scarce or non-existent even in the relatively well populated areas. The purpose of his short report is to update the record of the Harald Moltke Bræ, one for which a fairly detailed record exists from I9i 6 to the present.

\section{Physigal Setting}

The Harald Moltke Bræ is a large outlet glacier of the Greenland Ice Sheet, debouching into Wolstenholme Fjord at $76^{\circ} 35^{\prime} \mathrm{N}$. and $68^{\circ} \mathrm{W}$. near Thule Air Base, in north-western Greenland. The glacier is nearly $3^{\circ} \mathrm{km}$. long before losing its identity in the ice sheet proper and, at its terminus, is close to $7 \mathrm{~km}$. wide. The glacier and its drainage basin (determined from form lines on current maps) has an area of approximately $300 \mathrm{~km}^{2}$, of which about $200 \mathrm{~km} .^{2}$ represents the net accumulation zone. Two small glaciers and one sizeable glacier ("Blue Ice Valley" glacier) join the Harald Moltke Bræ from the south. The "Blue Ice Valley" component can be identified down-stream from its confluence with the Harald Moltke Bræ to the terminus by the presence of morainal material in the ice along the boundary.

The Harald Moltke Bræ is one of three glaciers which reach tide-water in Wolstenholme 
Fjord. The others, Knud Rasmussen Gletscher and Chamberlin Gletscher, are outlet glaciers of "North Cap", a local ice cap independent of the main ice sheet.

\section{Historical Background}

The positions of the terminus of the Harald Moltke Bræ and of the other glaciers entering Wolstenholme Fjord were first described in detail and sketched in I 916 by Koch (1928). Koch subsequently sketched the Harald Moltke Bræ terminus again in I923. Wright (1939) summarized Koch's work and added observations by Killerich (r929) and the personal recollections of Dundas inhabitants to the results of his own mapping to produce a map showing the location of the terminus for the years 1916, 1923, 1926, 1928, 1932, 1937 and 1938. Wright also mapped the terminal positions of the Knud Rasmussen and Chamberlin Gletscher for the years 1937 and $193^{8}$. Using the terminus position of 1938 as a base, Wright plotted the change in area of the glacier for the ${ }^{1}{ }^{16}$ to $193^{8}$ period. (Wright's observations are included in Figure 2.) Davies and Krinsley (1962) in a survey of north Greenland glaciers briefly reviewed Koch's and Wright's work and, in a sketch map modified from Wright, added the r946, r953, r 956 and 1959 positions of the terminus.

Wright's observations included a determination of the flow rate of the Harald Moltke Bræ by comparative photography. From the shift in position of crevasses identifiable in photographs taken from the same point (Station 416) one year apart he calculated a flow rate of approximately $30 \mathrm{~m}$./yr. in the central portion of the glacier, near the terminus.

\section{Measurements}

Vertical aerial photography of the terminus of the Harald Moltke Bræ is available for the years 1954, 1956 and 1962 . Mosaics were constructed from the photography of each of these years and the terminal positions then plotted on the r 954 mosaic. In addition the terminus position mapped by Wright in 1937, the 1946-47 position from Army Map Service I : I oo,ooo maps, and the 1965 position based on terrestrial photography and visual observation were also plotted. A map was then traced from the 1954 mosaic showing the above frontal positions and used for planimetric measurements.

Apart from two triangulation stations established by Wright, no identifiable horizontal control exists within the area photographed. Construction of the mosaic was done by matching identifiable points in adjacent photographs and making judicious adjustments where necessary. Horizontal scale was provided by calculating the distance between triangulation stations $4^{1} 6$ and 2 from Wright's data. Station $4^{16}$ was occupied in the field both for identification and comparative photographic purposes. Station 2 was not occupied and was not identified with certainty on the photography but its position, on the spit at the western end of Nunatarssuaq, severely limits its possible location. The most likely position was chosen from the photography and denoted as station 2 on the map. All measurements of area are subject to a \pm 5 per cent error because of the doubt in the length of the line from station $4^{1} 6$ to station 2.

Planimeter measurements were made of the change in area of the Harald Moltke Bræ using the plotted 1937 position as a base in order to relate these measurements to those of Wright. Several features on the glacier were identifiable in both the I954 and I956 photography and their change in position with respect to the line $4 \mathrm{r}^{\mathrm{r}} \mathrm{-2}$ enabled estimates of the flow rate to be made.

\section{RESUlts}

Figure I shows the positions of the terminus of the Harald Moltke Bræ for the years I937, 1946-47, 1954, I 956, 1962 and 1965. Figure 2 shows the area of the Harald Moltke tongue for several years from 1916 to 1965 with the $193^{8}$ position taken as the datum. 


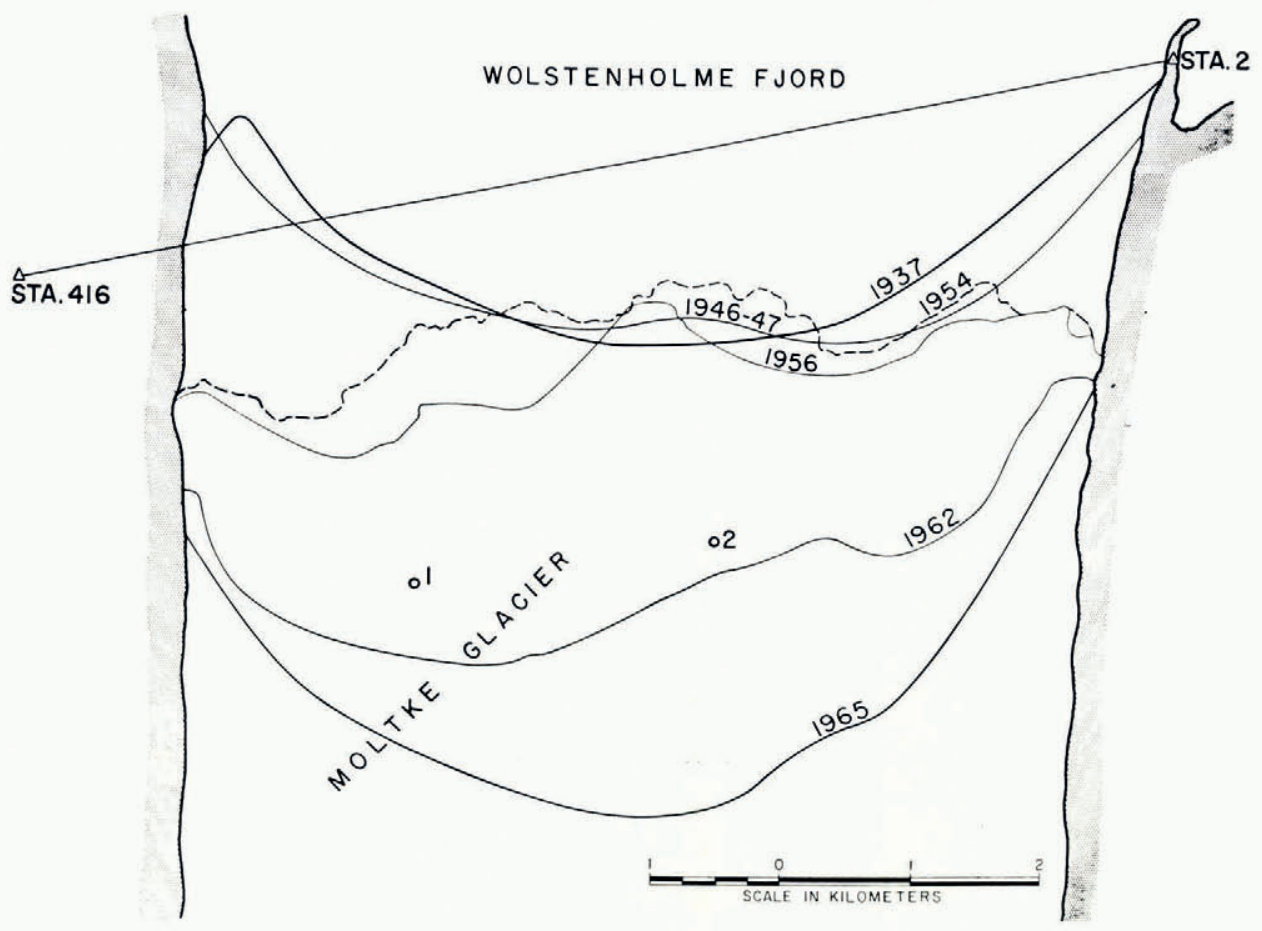

Fig. 1. Sketch map of Harald Moltke Bra showing terminus positions 1937 to 1965

The history of the Harald Moltke Bræ since I 916 has been one of general retreat, interrupted by a period of advance between I 926 and i 932 . The period between I 938 and I954 seems to represent a hiatus in the general retreat of the glacier.

An interesting facet of the Harald Moltke Bræ shown both in Wright's work and in the present study is the differing response of the main glacier and the "Blue Ice Valley" component. Koch's I 923 sketch shows two major tongues separated by a deep indentation, corresponding to the highly crevassed zone between the two ice streams. Later the main glacier retreated at a greater rate than the "Blue Ice Valley" component, while, in the mid I950's, the "Blue Ice Valley" component was in more rapid retreat. The conditions in the accumulation areas of both streams of the glacier causing changes at the terminus are probably very similar but because of the differing lengths of the two components, the response time to similar conditions is different.

Two points were identifiable in both the 1954 and 1956 photography. Their movement with respect to the fixed line 4I6-2 gave figures for flow of $260 \mathrm{~m}$./yr. for point $\mathrm{I}$ and $320 \mathrm{~m}$./yr. for point 2. The points and their respective positions are shown in Figure $\mathrm{I}$.

\section{Discussion}

During the period r 926 to r 928 the front of the Harald Moltke Bræ advanced $2 \mathrm{~km}$., indicating a minimum mean velocity of $1000 \mathrm{~m}$./yr. In actuality the velocity must have been somewhat higher to balance the effects of calving during the period. Ten years later, I $937^{-38}$, Wright's measurements showed velocities on the order of $30 \mathrm{~m}$. $/ \mathrm{yr}$. and by 1956 velocities had again increased, this time to approximately $300 \mathrm{~m}$./yr. Such variations in velocity are not 


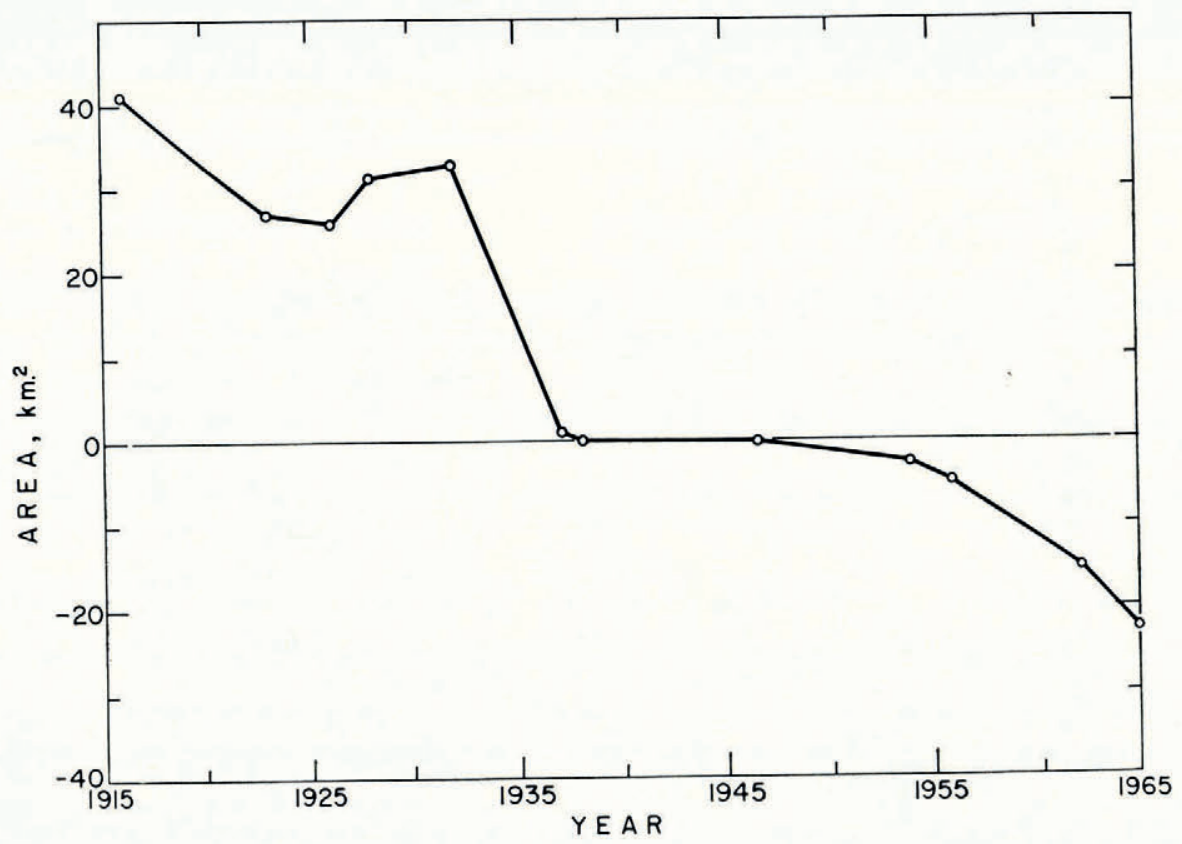

Fig. 2. Change in area of Harald Moltke Bra 1916 to 1965. Datum is $193^{8}$

unknown in glaciers but are scarcely common. It must also be noted that while the velocity increased by a factor of 10 from $193^{8}$ to 1956 , the recession of the glacier actually increased slightly during the same period.

Before speculating on possible causes of the somewhat erratic behavior of the Harald Moltke Bræ, let us consider certain of its physical aspects. The glacier ends in tide-water but, based on physical appearance, i.e. a prominent tidal melt zone and a lack of tidal cracks, it is apparently not afloat. At the terminus, buoyancy forces are probably such as to decrease significantly the shear stress at the bed of the glacier. It is difficult to estimate to what extent, if any, the glacier is frozen to its bed. Direct measurements of even surficial ice temperatures in the ablation zone of the glacier are lacking. The mean annual air temperature is on the order of $-10^{\circ} \mathrm{C}$. so it is reasonable to assume that the glacier has largely negative temperatures. Percolation from melt waters and from ice-dammed lakes into crevasses and along the margins may appreciably affect the englacial temperature regime. Pit studies at a few locations in the accumulation region indicate net accumulation from 40 to $60 \mathrm{~cm}$. of water equivalent yearly (Schytt, I955; Benson, 1962). An ice thickness profile was determined by Barnes and Taylor (unpublished) across the glacier using gravity methods at a point some I $5 \mathrm{~km}$. from the terminus and just down-glacier from the "Blue Ice Valley" glacier confluence. These measurements indicate that the ice is close to $150 \mathrm{~m}$. below sea-level. Depth soundings in Wolstenholme Fjord which could give information as to the thickness at the front indicate depths of the order of $80 \mathrm{~m}$. some $4 \mathrm{~km}$. from the 1937 position of the terminus. It is difficult from this to draw any conclusions as to ice thickness. A reasonable guess would be to consider the ice to be on the order of $100 \mathrm{~m}$. in thickness.

Despite the paucity of quantitative information on the Harald Moltke Bræ it is nevertheless of some use to speculate on the possible causes of its behavior, if for no other reason, to point out the areas where measurements must be taken in order to move from speculation to hypothesis. 
Mercer ( 1962 ) has pointed out that small changes in the elevation of the firn line can, in glaciers ending at sea-level in fjords, lead to rather spectacular changes in the position of the terminus. This is controlled in part by the shape of the fjord and in part is due to the fact that since part of the ablation area is already at a minimum elevation, increases or decreases in ablation can only occur by rather large changes in the total area or by increased calving. Thus the retreat of the Harald Moltke Bræ can be looked upon as the more or less normal reaction of a fjord-ending glacier to a rise of the firn line. This does not in any way supply an explanation for the observed changes in flow velocity.

It seems most probable that the observed changes in velocity are connected with the arrival of broad kinematic waves near the terminus. It has been shown both theoretically (Nye, 1958; Weertman, I958) and by direct measurement that traveling waves on glaciers move with a velocity of roughly four times the surface ice velocity. Nye (1962) has shown that at the snout the traveling wave velocity is approximately equal to the surface ice velocity while Weertman ( 1962 ) has shown that the interaction of the arrival of a kinematic wave and its effect on the controlling obstacle size for sliding, and on a subglacial water layer can lead to velocity changes (due to sliding) of up to 60 times.

It seems likely that the increased velocities noted in the Harald Moltke Bræ are connected with the arrival of kinematic waves at the terminus. These kinematic waves possibly could lead to an increase in sliding velocity if the bed, at least in the extreme lower portion, is near or at the pressure melting point.

It is hoped that in the future it may be possible to make more rigorous determinations of the velocity and to collect these data in a systematic manner.

MS. received 18 January 1966

\section{REFERENGES}

Barnes, D. F., and Taylor, L. D. Unpublished. A gravity survey of part of the Greenland Ice Cap near Thule. [U.S. Geological Survey report, written 1956.]

Benson, C. S. 1962. Stratigraphic studies in the snow and firn of the Greenland Ice Sheet. U.S. Snow, Ice and Permafrost Research Establishment. Research Report 70.

Davies, W. E., and Krinsley, D. B. 1962. The recent regimen of the ice cap margin in north Greenland. Union Géodésique et Géophysique Internationale. Association Internationale d'Hydrologie Scientifique. Commission des Neiges et Glaces. Colloque d'Obergurgl, $10-9-18-9$ 1962, p. 1 $19-30$.

Killerich, A. I929. Ny maaling af Moltkes Gletsjer. Geografisk Tidsskrift, Bd. 32, p. 181-82.

Koch, L. 1928. Contributions to the glaciology of north Greenland. Meddelelser om Gronland, Bd. 65, Nr. 2, p. $180-464$ Mercer, J. H. 1961. The response of fjord glaciers to changes in the firn limit. Fournal of Glaciology, Vol. 3, No. 29,
p. $850-58$.

Nye, J. F. 1958. Surges in glaciers. Nature, Vol. I81, No. 4621, p. 1450-51.

Nye, J. F. I 965 . A numerical method of inferring the budget history of a glacier from its advance and retreat. Journal of Glaciology, Vol. 5, No. 41, p. 589-607.

Schytt, V. I955. Glaciological investigations in the Thule ramp area. U.S. Snow, Ice and Permafrost Research Establishment. Report 28.

Weertman, J. I 958 . Traveling waves on glaciers. Union Géodésique et Géophysique Internationale. Association Internationale d'Hydrologie Scientifique. Symposium de Chamonix, $16-24$ sept. $195^{8}$, p. 162-68.

Weertman, J. ${ }^{1962}$. Catastrophic glacier advances. Union Géodésique et Géophysique Internationale. Association Internationale d'Hydrologie Scientifique. Commission des Neiges et Glaces. Colloque d'Obergurgl, 10-9-18-9 1962, p. $31-39$. Wright, J. W. 1939. Contributions to the glaciology of north-west Greenland. Meddelelser om Gronland, Bd. I25,
Nr. 3. 